\title{
Pretty Pictures
}

PRODUCTION DESIGN AND THE HISTORY FILM 
THIS PAGE INTENTIONALLY LEFT BLANK 


\section{Pretty Pictures}

PRODUCTION DESIGN AND THE HISTORY FILM

C. S. Tashiro 
Copyright $\odot 1998$ by the University of Texas Press

All rights reserved

Printed in the United States of America

First edition, 1998

Requests for permission to reproduce material from this work should be sent to Permissions, University of Texas Press, Box 7819, Austin, TX 78713-7819.

Library of Congress Cataloging-in-Publication Data

Tashiro, C. S. (Charles Shiro), 1957-

Pretty pictures : production design and the history film / by C. S. Tashiro. - 1st ed.

p. $\mathrm{cm}$.

Revision of thesis (Ph.D.)-University of Southern California.

Filmography: $p$.

Includes bibliographical references and index.

ISBN 978-0-292-78150-4

1. Motion pictures-Art direction. 2. Motion pictures-Setting and scenery. 3. Historical films. I. Title.

PN1995.9.A74T37 1998

791.43'0233-dc21

$97-4762$

ISBN 978-0-292-76181-0 (library e-book)

ISBN 978-0-292-78692-9 (individual e-book) 
To family and friends 
THIS PAGE INTENTIONALLY LEFT BLANK 